\title{
Robert A. Dahl, Econômico
}

\author{
Wanderley Guilherme dos Santos
}

Professor-titular (aposentado) da Universidade Federal do Rio de Janeiro (UFRJ), Rio de Janeiro, RJ, Brasil. E-mail: wanderleyguilhermedossantos@gmail.com.

$\mathrm{R}$ obert Dahl visitou inúmeras áreas da análise política: relações internacionais, política de bem-estar social, formas e desempenho das oposições, política local, análise constitucional, desigualdade política e econômica e, claro, democracia. Com uma produção sempre oportuna, raramente publicou volumes com mais de duzentas páginas. Eis a primeira razão do título. Seis de seus principais títulos sobre democracia - A Preface to Democratic Theory (1956), After the Revolution? (1970), Poliarchy (1971), On Democracy (1998), How Democratic is the American Constitution (2001) e On Political Equality (2006) não somam além de 1.113 páginas, incluindo prefácios, anexos, bibliografias e indexes. Em cada um deles é possível recortar teses que, em conjunto, revelam um rasto dos caminhos que a democracia pode trilhar para se estabelecer e, pois é obra humana, também para desmoronar. Mapas minimalistas permitindo extensas explorações. Eis a outra razão do título.

Desde logo sabemos que, em uma democracia ideal, é necessária a garantia de uma participação efetiva de todos os membros do demos (2006:9), mas somos igualmente advertidos de que recursos políticos, conhecimento, habilidades e incentivos são sempre e por toda parte desigualmente alocados (ibidem:51). Ainda mais, a desigual acumulação de recursos carrega uma horrível possibilidade: a de que as desi-

DADOS - Revista de Ciências Sociais, Rio de Janeiro, vol. 57, n-2, 2014, pp. 289 a 292. 
gualdades políticas alcancem um nível de onde não podem ser desalojadas (ibidem:85). Estas são desigualdades que exemplificam uma das respostas possíveis à pergunta sobre as condições que conduzem ao impedimento do desenvolvimento e estabilidade das condições democráticas (1998:31).

A poliarquia é um arranjo político que, sendo diferente da democracia representativa do século XIX (ibidem:90), requer sufrágio universal, entre outras cláusulas (ibidem:87). Entre as cláusulas essenciais ao desenvolvimento da democracia encontra-se um dos axiomas mais relevantes e importantes da teoria política democrática: quanto mais os custos da repressão excedem os custos da tolerância, maior a chance [de sucesso, WGS] de um regime competitivo (1971:15). A preocupação com a origem e estabilidade da democracia poliárquica (assim denominada porque não privilegia apenas um princípio: riqueza, raça, status etc.) é permanente, expressa nas análises comparativas das instituições americanas em face de outras, incluindo o ponto quase sagrado do sistema eleitoral. Examinando criticamente o sistema eleitoral americano e inglês de maiorias relativas (o denominado voto distrital majoritário, que Dahl abomina), precisamente em sua avaliação crítica da Constituição dos Estados Unidos, indaga:

Mais do que um século de experiência com alternativas, não seria o tempo finalmente de abrir nossas mentes para a possibilidade de que o sistema vigente (das maiorias relativas) pode ser apropriado para corridas de cavalos (o primeiro a cruzar a linha é o vencedor), mas pode não ser o melhor em eleições em um país democrático tão grande e diverso quanto o nosso? Não poderíamos também desejar considerar as possíveis vantagens de um sistema pluripartidário [de representação proporcional - WGS]?" (2001:60).

A distribuição desigual de recursos políticos sempre permanece como ameaça a uma concentração ou radicalização que faça ruir os fundamentos da poliarquia, independente das instituições partidárias e eleitorais. Em cada dobra da atividade política se esconde uma possibilidade de assimetrias, inclusive em instituições emblemáticas como a disputa parlamentar (1970:passim). Ao final de processos semelhantes, envolvendo custos de tolerância e de opressão, radicalização do sistema de crenças e desigualdades encontra-se o cenário mais temido: uma polarização entre forças contrárias e igualmente poderosas levando a um impasse dificilmente solúvel nos quadros democráticos (1956:119 e ss.). 
É minha avaliação que a análise das características do sistema político democrático de Robert A. Dahl será profícua enquanto perdurarem as condições econômicas que lhe servem de sustentação empírica. Aperfeiçoamentos são inevitáveis, é claro, mas dificilmente suas teses principais serão falsificadas. Especialmente com igual economia.

(Recebido e aprovado para publicação em maio de 2014) 


\section{Wanderley Guilherme dos Santos}

\section{REFERÊNCIAS BIBLIOGRÁFICAS}

DAHL, Robert. (1956), A Preface to Democratic Theory. Chicago, University of Chicago Press.

. (1970), After the Revolution: Authority in a Good Society. New Haven, Yale University Press.

. (1971), Poliarchy: Participation and Opposition. New Haven, Yale University Press. . (1998), On Democracy. New Haven, Yale University Press.

. (2001), How Democratic is the American Constitution. New Haven, Yale University Press.

. (2006), On Political Equality. New Haven, Yale University Press. 